INSIGHTS INTO REGIONAL DEVELOPMENT

ISSN 2669-0195 (online) http://jssidoi.org/IRD/

2021 Volume 3 Number 4 (December)

http://doi.org/10.9770/IRD.2021.3.4(3)

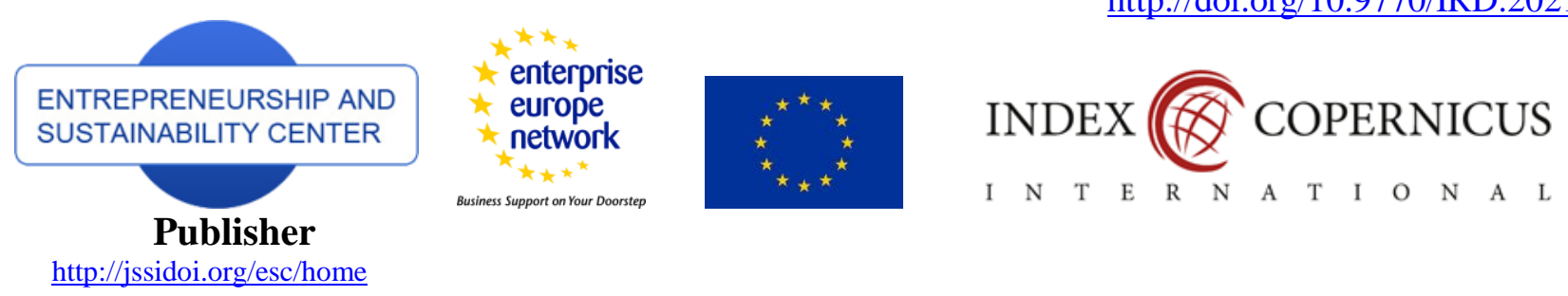

\title{
THE IMPACT OF COVID-19 ON THE FINANCIAL PERFORMANCE: A CASE STUDY OF THE LITHUANIAN TRANSPORT SECTOR
}

\author{
Paulina Periokaite ${ }^{1}$, Nomeda Dobrovolskiene ${ }^{2}$ \\ 1,2 Department of Financial Engineering Faculty of Business Management, Vilnius Gediminas Technical University \\ (VILNIUSTECH), Sauletekio al. 11, LT-10223, Vilnius, Lithuania \\ E-mails: ${ }^{1}$ paulina.periokaite@stud.vilniustech.lt; ${ }^{2}$ nomeda.dobrovolskiene@vilniustech.lt
}

Received 8 September 2021; accepted 15 November 2021; published 30 December 2021

\begin{abstract}
The changing global situation due to the outbreaks of COVID-19 is causing a crisis, not only in terms of healthcare but also in economic terms. Companies are faced with hasty decisions to avoid financial problems or even bankruptcy. Both in theory and practice, there are often more negative than positive effects of the coronavirus outbreak on transport sector business, but this topic has not yet been sufficiently explored due to the novelty of the situation and the divergent opinions of authors on some matters. The most significant impact is emphasised in the case of air transport, and the least studied area is road transport activity, which in Lithuania comprises the largest share of all modes of transport. It is observed that transport companies experience a decline in profitability indicators during the first wave of COVID-19. In the course of the investigation, the expert survey identified the most affected profitability and liquidity indicators of road transport companies. Relative financial indicators and a study of the financial results of coronavirus-related quarantine carried out using paired correlation analysis showed that there is an unequal connection between the number of days of quarantine in Lithuania and the relative financial indicators of road transport companies. Therefore, the crisis caused by COVID-19 is likely to have a positive or negative impact on the financial performance of a company, depending on the company's activity. However, in some cases, there may be no impact at all. The monitoring of the constantly changing coronavirus crisis and the corresponding economic situation is an important immediate and continuous participation in the monitoring and control of the financial situation of companies.
\end{abstract}

Keywords: coronavirus, COVID-19, financial indicators, transport sector; road transport companies, economic crisis.

Reference to this paper should be made as follows: Periokaite, P., Dobrovolskiene, N. 2021. The impact of COVID-19 on the financial performance: a case study of the Lithuanian transport sector. Insights into Regional Development, 3(4), 34-50.

http://doi.org/10.9770/IRD.2021.3.4(3)

JEL Classifications: A10, C10, C83, M20

\section{Introduction}

In early 2020, the whole world was faced with an emergency due to the sudden spread of coronavirus, which causes COVID-19, a serious infectious disease. The disease spreads rapidly and is very contagious; thus, the existence of this virus changes the daily lives of people and also affects global supply chains, consumer demand, and financial markets; tourism activities change, businesses fail, economic growth stops, oil prices change, etc. The transport sector is one of the sectors that is affected in one way or another by this coronavirus crisis. According to the data of the Department of Statistics of Lithuania, in 2020 the revenue of transport and storage companies decreased by $1.67 \%$, while profit before taxation decreased by as much as $41.03 \%$, and 79 companies 


\section{INSIGHTS INTO REGIONAL DEVELOPMENT}

ISSN 2669-0195 (online) http://jssidoi.org/jesi/

2021 Volume 3 Number 4 (December)

http://doi.org/10.9770/IRD.2021.3.4(3)

operating in the transport sector ceased their activities (Department of Statistics of Lithuania, 2021). Nearly all companies experienced financial difficulties during the first wave of coronavirus. Global financial problems caused by coronavirus are unexpected; therefore, dealing with difficulties is a difficult, labour-intensive task for governments and company management authorities alike. Scientists conduct theoretical and practical research, predict possible scenarios, and look for measures to solve arising problems. It is important to determine how the transport sector is affected by the coronavirus outbreak according to the latest financial data of Lithuanian transport companies.

The research question is how to assess the impact of the coronavirus outbreak on the financial results of the transport sector properly?

The research object is the financial results of Lithuanian road transport companies.

The research goal is to justify and assess theoretically the impact of the coronavirus outbreak on the financial results of undertakings in the transport sector.

Tasks:

1. To study scientific literature on the impact of the coronavirus outbreak on the transport sector.

2. To review the methods used to determine the impact of the coronavirus outbreak on the financial results of the transport sector.

3. To conduct empirical research to determine the financial indicators of Lithuanian road transport companies most affected by the coronavirus outbreak.

The hypothesis is that the coronavirus outbreak affects the financial results of Lithuanian road transport companies differently.

The article consists of the introduction, five sections, conclusions, and references. The first part describes the transport sector, its market, and the most important financial indicators. The focus of the theoretical part is on the crisis caused by the coronavirus outbreak, its impact on the economy and on the transport sector. The second methodological part deals with research methods used to assess the impact of coronavirus on the financial results of road transport companies and presents research assumptions and characteristics of the data sample. Sections 35 identify the impact of the coronavirus outbreak on the financial results of road transport companies. Conclusions are presented at the end of the article.

\section{The theoretical impact of coronavirus on the transport sector}

In scientific literature, the economic impact of coronavirus is assessed differently and it is emphasised that a more accurate assessment requires analysis of individual sectors; however, there is a shared opinion that the virus outbreak interferes with economic growth and causes problems in many areas. Disruptions in supply chains and international trade, decreased employment and slowed economic growth are the main first consequences noticed by scientists as early as during the first wave of coronavirus (Ajam, 2020), (Nicola et al., 2020), (Maryla et al., 2020). Demand for essential and non-essential goods changed fundamentally. The demand for essential goods increased dramatically because people began creating stocks, fearing that quarantine or illness will prevent them from leaving the house, while the demand for non-essential and luxury goods decreased significantly (Sahoo \& Ashwani, 2020). One of the indicators assessing the level of economic development, gross domestic product (GDP), decreased even in highly developed countries. In countries such as China or the US, a decrease in GDP growth rate is observed. In Lithuania, based on economic indicators, public debt increased, GDP decreased, and unemployment increased (Poteliūnienè et al., 2020). These are only a few general problems that emerged in spring 2020, occurred again in autumn of the same year and continued in 2021, affecting almost all sectors. Science states that this unprecedented situation caused not only a social, but also an economic crisis, which, 


\section{INSIGHTS INTO REGIONAL DEVELOPMENT}

ISSN 2669-0195 (online) http://jssidoi.org/jesi/

2021 Volume 3 Number 4 (December)

http://doi.org/10.9770/IRD.2021.3.4(3)

depending on the location and sector of activity, is expressed differently. It is predicted that coronavirus may cause 5 or more global outbreaks (Barua, 2020).

At the beginning of 2020, the transport sector faced a sudden change in the supply and demand of services due to the coronavirus outbreak. The unbalanced market led to urgent decisions, which caused some companies to cope quite well with the difficulties encountered, while other companies suffered huge losses or even closed their businesses. An overview of scientific sources shows that the coronavirus crisis has a different effect on individual modes of transport. As early as during the first month of the coronavirus outbreak, air transport faced a sharp decline in demand for passenger transport caused by the closure of national borders and the resulting suspension of flights. The recorded decrease in the number of passengers during quarantine was the most significant in the history of aviation (Petryk, 2020). Meanwhile, freight air transport faced the opposite challenges: demand for cargo flights increased by $\sim 12 \%$ in spring 2020 (ICAO, 2020). Airlines took advantage of the situation when aircraft were stored at airports and adapted passenger aircraft for cargo transportation, thereby increasing the capacity of cargo aircraft (Serrano \& Kazda, 2020). However, although there were enough aircraft for cargo transportation, the costs of such flights increased several times, and, in some cases, a dozen times. In some countries, governments apply a support policy to companies affected by COVID-19, including airlines (Abate et al., 2020).

Similar effect is felt on all public transport, which becomes the location of COVID-19 spread and infection. The study on public transport changes in Stockholm monitored public transport indicators in the first half of 2020 and showed that in March, COVID-19 regulations introduced the country reduced the number of passengers in public transport by about $60 \%$ (Jenelius \& Cebecauer, 2020). Public transport companies' revenues were falling, while costs were rising because it was impossible to completely abandon public transport in many locations. There is also a strong correlation between the spread of coronavirus and the demand for public transport because not only coronavirus has a negative impact on public transport activities, but also the use of public transport poses a threat to the accelerated spread of the virus (Ozaydin \& Ulengin, 2020). Reduced demand for public transport encourages the use of private cars and bicycles and motivates walking short distances.

In the context of the effects of coronavirus, road and maritime transport are analysed less often, but this does not mean that the effect on these modes is negligible. The demand for maritime cargo from and to China decreased as a result of the pandemic and the closure of some factories in China (Tardivo et al., 2020). Some maritime cargo was transported by rail. However, this trend is not the same in all countries and mostly applies to East Asia. Rail transport is the least negatively affected by coronavirus. While passenger movement decreased, railways became more important and more in demand for cargo transportation (Ozaydin \& Ulengin, 2020). This mode of transport is superior to maritime transport in terms of service speed, and superior to air transport in terms of prices.

Scientists are less focused on determining the effects of coronavirus on road transport companies. After quarantine was imposed in China, some roads in the country were closed (Liu et al., 2020), but this caused a disruption in the movement of goods in the country. European countries implemented border closures and border checks, which resulted in queues at border sections and problems in the transportation of urgent and perishable goods (Loske, 2020). In Lithuania, road transport companies comprise the largest share in comparison to other modes of transport (Lietuvos statistikos departamentas, 2021), while the total transport sector in the country accounts for about 12-13\% of GDP, making it one of the most important sectors. The transportation of passengers and cargo by road during the first wave of COVID-19 was restricted for security purposes. The number of passenger intercity routes decreased in order to reduce unnecessary domestic travel. Freight transport was temporarily confronted with self-isolation of drivers who had returned from trips abroad, but this restriction was quickly removed due to its negative impact on company activities. COVID-19 encouraged road transport companies to look for safer ways of carrying out their activities regardless of the pandemic, thus encouraging the development of no-contact deliveries and automated vehicle unloading/loading stations in order to reduce the 


\section{INSIGHTS INTO REGIONAL DEVELOPMENT}

ISSN 2669-0195 (online) http://jssidoi.org/jesi/

2021 Volume 3 Number 4 (December)

http://doi.org/10.9770/IRD.2021.3.4(3)

number of physical contacts. There is currently a lack of research in scientific literature into specific changes in financial results in the road transport sector.

As regards the impact of COVID-19 on the financial results of companies, the results of companies operating in different sectors were studied in China and one of the most important indicators - return on assets (ROA) - was emphasised. The study shows that there is a strong negative impact on the ROA indicator in tourism and transport companies in China (Rababah et al., 2020). In other sectors, the negative dependence of this indicator on COVID19 is observed as well (Hu \& Zhang, 2021). Changes in income and costs are important, too. There is a noticeable decrease in sales revenue caused by lower demand or changing prices on the market (Shen et al., 2020). However, the impact of COVID-19 on financial results cannot be considered to be exclusively negative because impact on individual sectors of the economy may vary. A study carried out in Malaysia analysed different financial indicators showing that some of the companies analysed had improved their financial results in the presence of COVID-19 (Khatib \& Nour, 2021). The authors consider the following indicators to be particularly significant: ROA (return on assets) and ROE (return on equity). Studies stress that, due to the novelty of the situation, more in-depth research is needed after more time has passed since the start of the pandemic, so there is no consensus on how COVID-19 affects financial indicators of companies.

Analysis of scientific literature shows that the coronavirus crisis may have different effects on the activities of companies engaging in different modes of transport. It is obvious that during the coronavirus pandemic the impact will change and it will cause more different problems. In this case, it is important to investigate the impact of coronavirus on the financial results of Lithuanian transport sector companies in 2020.

\section{Methodology for studying the impact of the coronavirus crisis on financial results}

In order to study how and what financial indicators are affected by the coronavirus crisis, it was decided to conduct an expert survey, to check the compatibility and reliability of expert opinions, and to calculate financial relative indicators and the paired correlational relationship between the number of quarantine days in Lithuania (dependent variable) and financial relative indicators (independent variables) based on the results of the expert survey. It is assumed that in Lithuania, only COVID-19 could have caused the most significant changes in financial results, while other economic factors remained unchanged. The methodological chart is shown in Figure 1.

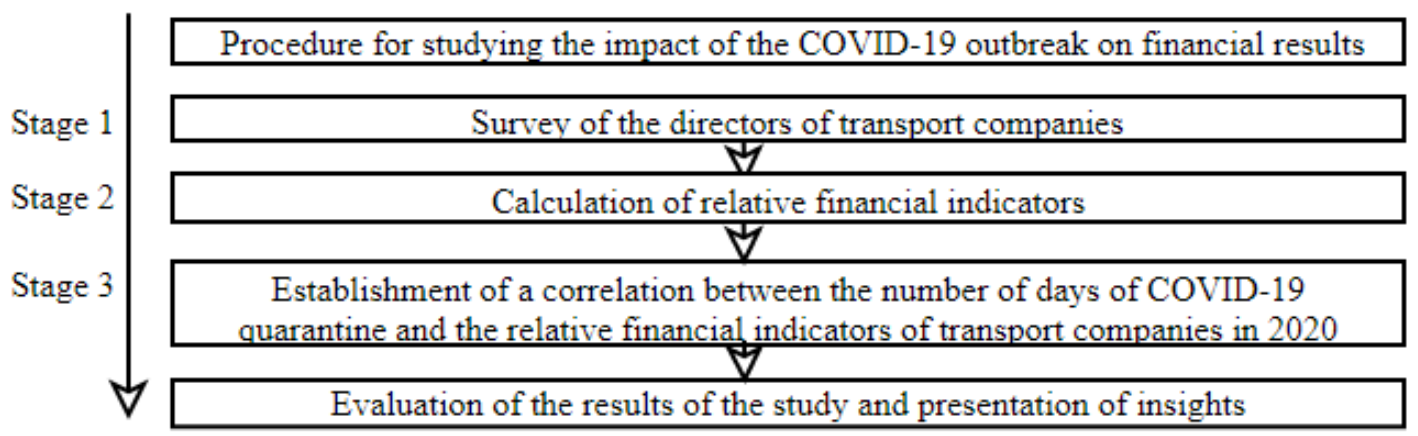

Figure 1. Methodology for the impact of the coronavirus crisis on financial results 


\section{INSIGHTS INTO REGIONAL DEVELOPMENT}

ISSN 2669-0195 (online) http://jssidoi.org/jesi/

2021 Volume 3 Number 4 (December)

http://doi.org/10.9770/IRD.2021.3.4(3)

The study starts with an expert survey using an anonymous written survey. The expert evaluation is carried out in several stages:

1. A questionnaire-based survey is created (see Annex 1).

2. Respondents are selected and interviewed.

3. The compatibility and reliability of expert opinions is calculated.

4. The weight of the indicators to be assessed is calculated.

The experts were asked to answer questions by selecting choices (questions 1-7, 9-10), to rank certain financial indicators (question 8), and to assess the situation from the perspective of the represented company in open questions (questions 11-12). For questionnaire replies in question 8, a ranking scale is provided for arranging answers in ascending or descending order (Kardelis, 2017). This question is crucial for the follow-up of the study: calculations of the weight of indicators, the compatibility and reliability of expert opinions. When performing an expert survey, it is important to select respondents who have competence in the subject being investigated (Baležentis \& Žalimaite, 2011). Ten experts who work or lead road transport companies, have at least five years of experience in the transport sector, know the company's finances and work in 2020-2021 during the COVID-19 pandemic were selected. The quality of the study and the reliability of the results obtained depend on the competence of the experts selected.

The calculation of the compatibility of experts is a necessary step because further study decisions are taken on the basis of expert opinions (Podvezko, 2004). The experts' compatibility is checked according to the coefficient of concordance, also known as Kendall's coefficient (Kendall, 1970). Formula for Kendall's coefficient of concordance:

$$
W=\frac{12 \bar{s}}{k^{2}\left(n^{3}-n\right)^{\prime}}
$$

where: $W$ is the coefficient of concordance; $S$ is the sum of squared average ranks; $k$ is the number of experts; $n$ is the number of indicators being compared.

When the value of the coefficient of concordance is close to one, expert opinions are considered to be compatible, and if the value is close to zero, opinions vary significantly (Podvezko, 2004). When $n$ is more than 7, it is necessary to determine the weight of the coefficient of concordance, or reliability, which is assessed using the Pearson criterion $-X^{2}$ (Bilevičienė \& Jonušauskas, 2011). It is a random value distributed on the $X^{2}$ distribution with the degree of freedom $v=n-1$ and the selected weight level $\alpha=0.05$. This is the basis for finding a critical value. For the coefficient of concordance to be significant, $X^{2}$ must be higher than the $X_{\mathrm{kr}}{ }^{2}$ value. The Pearson criterion $X^{2}$ is calculated according to the formula (2):

$$
X^{2}=W \times k \times(n-1),
$$

where: $W$ is the coefficient of concordance; $k$ is the number of experts; $n$ is the number of indicators being compared.

In this case, the coefficient of concordance and its reliability apply only to question 8 of the survey, where experts rank financial indicators from unaffected (value equals 1) to highly affected (value equals 10) by COVID-19, without assessing positive or negative effects. The same rank can be assigned to more than one indicator.

Since the goal of the expert survey is to identify the financial indicators of road transport companies that were affected by the coronavirus crisis the most, it is appropriate to set weighting coefficients for each of the indicators according to the results of the questionnaire. In other words, their weight is determined as follows:

1. The average value of indicators assessment is calculated:

$$
\overline{t_{j}}=\frac{\sum_{k=1}^{r} t_{j k}}{r},
$$


2. The weight of the indicators is calculated:

$$
w=\frac{\sum_{j=1}^{n} \bar{t}_{j}}{t_{j}},
$$

where: $w$ is the weight of the indicator; $t_{j}$ is the values of the estimates; $r$ is the number of experts.

The sum of the weight of all indicators must be equal to 1 . The weight of an indicator is the weighting coefficient w, which helps to rank the financial indicators: in this case, from the most affected to the least affected by the quarantine. The use of the expert evaluation is valuable in combination with other methods, for confirming or refuting the results obtained by the survey.

Financial relative indicators allow assessing the financial activity of companies more objectively and more comprehensively; using this method, it is possible to compare several companies of different sizes in the same sector (Bliekienè \& Stundžienè, 2012; Kazakevičius \& Jakštas, 2018). Many different indicators may be calculated according to financial statements, so the expert survey helps to select indicators relevant to the problem under investigation better. There is no goal to calculate all possible relative indicators because too many of them may not show and not highlight the real situation (Mackevičius \& Valkauskas, 2010). The study uses seven relative indicators that are part of profitability (GPR, NPR, ROA, ROE), liquidity (CLR, TSR), and debt (TDR) groups of indicators. The indicators are shown in Table 1.

Table 1. Relative indicators and their formulas

\begin{tabular}{|c|c|c|}
\hline Name & Code & Formula \\
\hline Gross profitability & GPR & $G P R=G P / S R$ \\
\hline Net profitability & NPR & $N P R=N P / S R$ \\
\hline Return on assets & ROA & $R O A=N P / A$ \\
\hline Return on equity & ROE & $R O E=N P / E C$ \\
\hline Total debt ratio & TDR & $T D R=L / A$ \\
\hline Current liquidity ratio & CLR & $C L R=C A / C L$ \\
\hline Total solvency ratio & TSR & $T S R=E C / L$ \\
\hline
\end{tabular}

Source: compiled by the authors, based on (Delen et al., 2013; Fenyves et al., 2020; Kadim et al., 2020; Kazakevičius \& Jakštas, 2018; Linares-Mustarós et al., 2018; Thacker et al., 2020). Notes: In the table, GP is gross profit, $S R$ is sales revenue, $N P$ is net profit, $A$ is assets, $E C$ is equity capital, $L$ is liabilities, $C A$ is current assets, and $C L$ is current liabilities.

An important aspect of the analysis of the financial situation according to relative indicators is the use of absolute indicators expressed in the same units, obtained from the same period and by using the same methodology. For the purpose of the study, the financial data of five Lithuanian road transport companies from profit (loss) and balance sheets from 2015 to 2020 are used. Companies refuse to make their names public, so they are assigned random letters: "J", "R", " $\mathrm{B}$ ", "N" and "K". It is assumed that the only factor contributing to substantial changes is the restrictions caused by COVID-19 quarantine. In order to obtain the most accurate results of the study, the method of calculating the relative indicators is combined with paired correlation analysis.

The last stage of empirical research is the calculation of the correlation coefficient. The paired correlation determines the linear relationship between the two variables X (independent) and Y (dependent) (Pabedinskaite \& Činčikaitè, 2016). This method aims to determine the impact of the number of days of quarantine caused by the spread of coronavirus in Lithuania on the financial results of road transport companies. The same relative indicators are used, but only those calculated according to the financial statements for the quarters of 2020. Quarantine days in Lithuania are counted accordingly by quarter (see Table 2). The dependent variable $\mathrm{Y}$ is the number of quarantine days and the independent variables $\mathrm{X}$ are the relative quarterly indicators. 
Table 2. Data for correlation analysis - the number of quarantine days in Lithuania in 2020, by quarter

\begin{tabular}{|c|c|}
\hline Number of days $(Y)$ & Period \\
\hline 16 & 1 quarter (3 months) \\
\hline 93 & 2 quarters (6 months) \\
\hline 93 & 3 quarters (9 months) \\
\hline 148 & 4 quarters (12 months) \\
\hline
\end{tabular}

For correlation calculations, Excel is used. Using the CORREL function, in which values $X$ and $Y$ are highlighted, the correlation coefficient is obtained. Correlation coefficient values are between -1 and 1 . The closer the value is to zero, the lower the correlation, and the closer the value is to -1 or 1 , the higher the correlation. When the coefficient is positive and close to $1, X$ increases if $Y$ values increase, and when the coefficient is negative, $X$ increases if $Y$ decreases (Baak et al., 2020). Then, the weight of the coefficient is assessed using the statistic t, which is calculated according to Formula 5 (Pabedinskaite \& Činčikaitè, 2016):

$$
t^{e k s p}=\left|r \sqrt{\frac{n-2}{1-r^{2}}}\right|,
$$

Where $t^{\exp }$ is Student's statistic $t$ calculated from the sample; $r$ is the correlation coefficient; $n$ is the number of observations.

The critical value of $t$ is calculated using the TINV function at the weight level $\alpha=0.05$, the number of degrees of freedom $k=n-2$. When texp>tkr, it can be concluded that the correlation is significant. After the correlation analysis, the relative financial indicators of each of the road transport companies concerned are determined, where changes to the indicators were possibly influenced by the number of quarantine days in Lithuania in 2020.

\section{Results of the survey and insights of the directors of Lithuanian road transport companies}

The expert survey was carried out in May 2021. Ten experts from road transport companies operating in Lithuania participated in the survey. The experts' compatibility was calculated according to Kendall's coefficient of concordance, based on the financial indicators assessed in question 8 of the survey. The resulting Kendall's coefficient of concordance (obtained according to Formula 1) is $W=0.2244$, so it can be said that expert opinions are barely compatible. Such a coefficient value may indicate that the companies represented by these experts and the financial results of the companies were affected differently during the COVID-19 period. The coefficient of concordance is considered reliable when the Pearson criterion $X^{2}$ is higher than the $X_{k r}^{2}$ value. In this case, $X^{2}=15.71, X_{k r}{ }^{2}=14.07$, so it can be assumed that the expert compatibility coefficient is reliable and significant.

The survey showed that the companies represented by $70 \%$ of the respondents experienced COVID-19 quarantine effects (Figure 2). None of the companies stopped their activities during quarantine, but some of the activities of $50 \%$ of the companies were restricted or suspended (Figure 2). 
INSIGHTS INTO REGIONAL DEVELOPMENT

ISSN 2669-0195 (online) http://jssidoi.org/jesi/

2021 Volume 3 Number 4 (December)

http://doi.org/10.9770/IRD.2021.3.4(3)

\section{Is your company affected by the announced COVID-19 quarantine?}

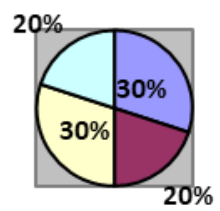

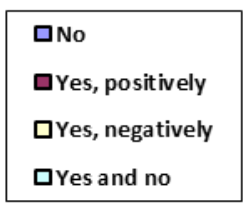

\section{Were the activities of the company stopped as a result of the quarantine \\ announced in the country?}

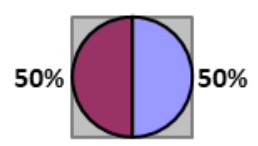

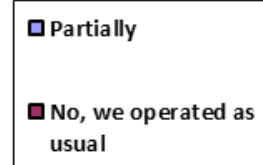

Figure 2. Answers to the expert survey (questions 1 and 2)

Since the activities of the companies were not stopped, the third question was skipped by all respondents. During the quarantine period, the demand of $40 \%$ of the companies increased, remained stable for a third of the companies, and declined for the same number of companies (Figure 3). The results of the demand depend on the purpose (cargo or passengers) of transport and on the services provided at a local or international level. Meanwhile, supply remained stable for $50 \%$ of the companies, decreased for $30 \%$ of the companies (mainly due to employees falling ill and a lack of opportunities for working remotely), and increased for $20 \%$ of the companies (Figure 3).

\section{How did the demand for services provided by the company change?}

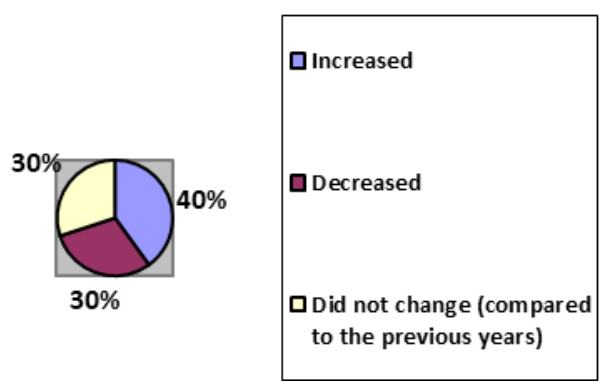

\section{How did the supply of services provided by the company change?}

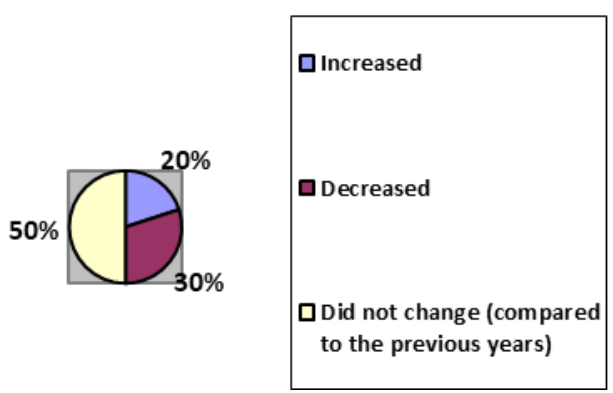

Figure 3. Answers to the expert survey (questions 4 and 5)

During quarantine, $20 \%$ of the companies surveyed lost suppliers and customers because of forced closure of businesses (Figure 4). COVID-19 affected as many as 50\% of the companies participating in the survey in one way or another (Figure 4), according to the respondents. 
INSIGHTS INTO REGIONAL DEVELOPMENT

ISSN 2669-0195 (online) http://jssidoi.org/jesi/

2021 Volume 3 Number 4 (December)

http://doi.org/10.9770/IRD.2021.3.4(3)

\section{Did the company lose \\ suppliers/customers because of the quarantine?}

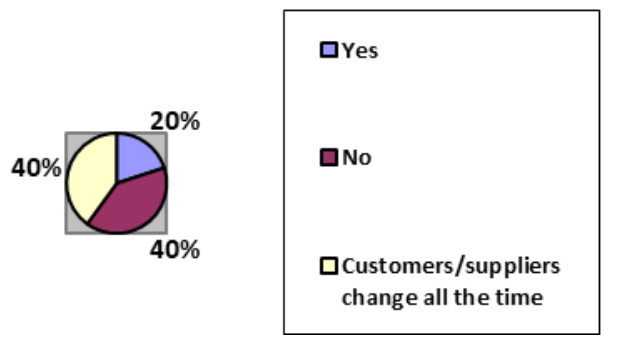

\section{Did the COVID-19 pandemic affect the company's financial indicators?}

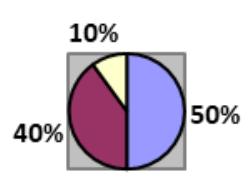

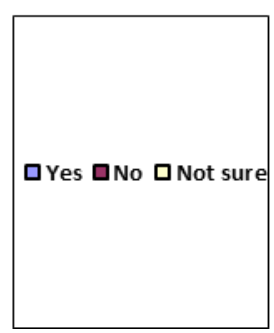

Figure 4. Answers to the expert survey (questions 6 and 7)

Thirty percent of the companies surveyed received support from the Government of the Republic of Lithuania for their business regarding losses incurred because of COVID-19 (Figure 5). Twenty percent of them answered that the support was not sufficient and did not solve the financial problems of the company, while $10 \%$ said that the support was useful, but only partially. Thus, measures envisaged by the state do not help to restore business activity, or help only partially.
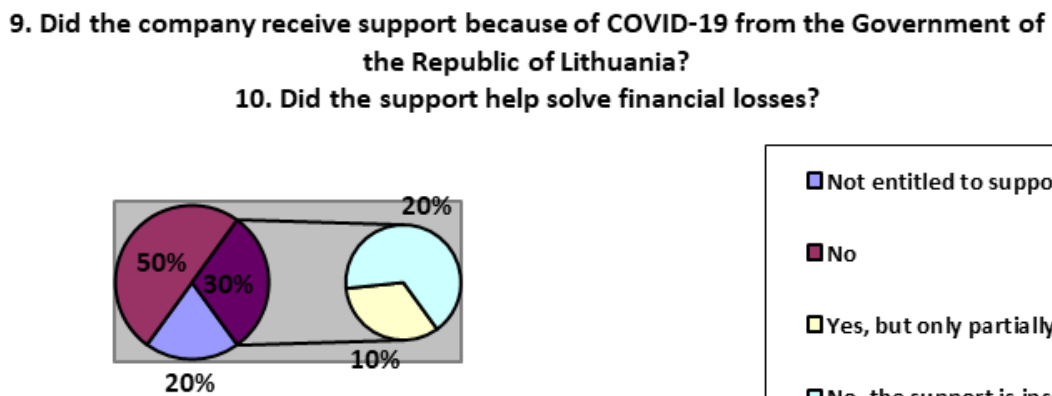

$\square$ Not entitled to support
$\square$ No
$\square$ Yes, but only partially
$\square$ No, the support is insufficient

Figure 5. Answers to the expert survey (questions 9 and 10)

The survey contained open questions (questions 11 and 12), where experts presented the actions taken to deal with the difficulties caused by the COVID-19 quarantine. Some of the respondents used subsidies for downtime, partial interest compensation, deferral of loans and taxes, and rent compensation. The companies also agreed on the reduction of the rental fee, fired some of their employees, sought new areas of activity and partially reoriented their activities. If the pandemic situation ends by 2022 (question 12, part (a)), the experts made possible financial forecasts for the companies: companies that operated in a stable manner and were not affected by the quarantine should continue their activities with similar results and growth trends. Companies that have suffered financial losses are likely to recover in 2-3 years, while others claim that one year will be enough. Companies that have experienced profit growth believe that the results will remain the same or will continue to grow if it does not depend on COVID-19. When profit growth is associated with the COVID-19 pandemic, the results should be slightly worse or they should reach pre-pandemic levels after the end of the pandemic. If the pandemic situation continues for 2-3 years (question 12, part (b)), the experts believe that adapting to pandemic conditions will enable companies to restore their financial indicators to previous levels, and a reorganisation of the nature of their activities could improve their results over a period of 1-2 years. Others believe that in this case the results would stabilise after at least 5-7 years, while those whose results did not suffer do not comment on this issue in detail and expect the company to maintain a stable financial condition. 
Each expert assessed the impact on the indicators presented in the survey (question 8), which was possibly caused by the COVID-19 quarantine in 2020. According to experts' evaluations, the weight of these indicators was estimated and they were ranked from 1 to 8 (from the most affected to the least affected). The results are shown in Table 3.

Table 3. The weight of indicators according to the experts' evaluation

\begin{tabular}{|c|c|c|}
\hline Indicator & Indicator weight $(w)$ & Rank \\
\hline Gross profit & 0.1462 & 3 \\
\hline Net profit & 0.1840 & 1 \\
\hline Sales income & 0.1415 & 5 \\
\hline Cost of sales & 0.1274 & 6 \\
\hline Current assets & 0.1061 & 8 \\
\hline Fixed assets & 0.0566 & 2 \\
\hline Current liabilities & 0.1509 & 7 \\
\hline Non-current liabilities & 0.0873 & 5 \\
\hline
\end{tabular}

According to the results in Table 3 and the assessment of the weight of the indicators (based on Formulas 1 and 2), the most significant, in other words, the most affected during COVID-19, indicator is net profit, which represents the final financial result of a company, as well as current liabilities and gross profit. The least significant in the context of COVID-19 is fixed assets and non-current liabilities.

\section{Changes in the financial relative indicators of Lithuanian road transport companies from 2015 to 2020}

The completed calculations of the relative indicators highlighted various trends. GPR shows the benefits of the sale of services, i.e. how much gross profit is contained in each sales euro. Above $15 \%$ shows good condition, less than 7\% means unsatisfactory condition (Mackevičius \& Valkauskas, 2010). In all companies, GPR shows good condition, except for company "R" in 2019 when this indicator was equal to 6.66\% (see Figure 6). The dynamics of the GPR indicator from 2015 to 2020 does not show a significant COVID-19 impact.

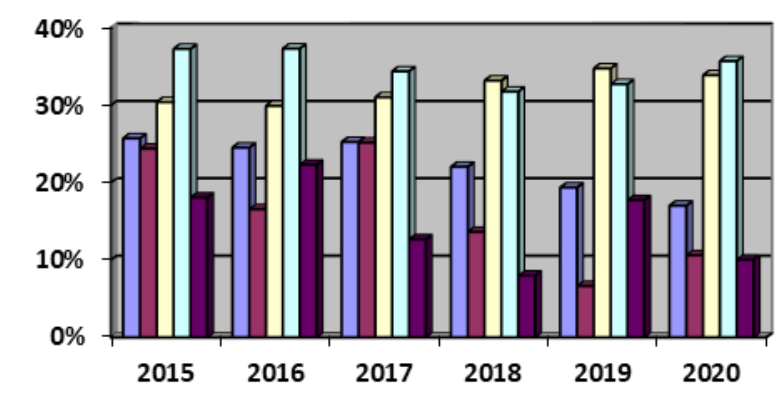

口Company J $\square$ Company R $\square$ Company B $\square$ Company K aCompany N

Figure 6. Gross profitability (GPR) in Lithuanian road transport companies from 2015 to 2020, \%

NPR assesses the efficiency of the company's activities and shows how much net profit is contained in each sales revenue euro. Above $10 \%$ is considered to be a good situation and below 5\% means a bad one (Mackevičius \& Valkauskas, 2010) and the company needs to take action to improve competitiveness. NPR calculation results are shown in Figure 7. 


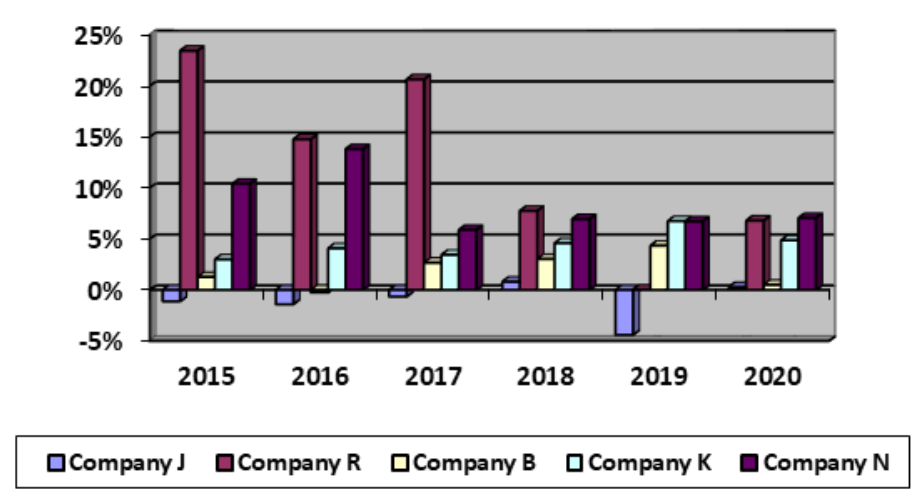

Figure 7. Net profitability (NPR) in Lithuanian road transport companies from 2015 to 2020, \%

In companies "J", "B" and "K", the NPR indicator was below 5\% from 2015 to 2020, indicating that the company needs innovation and an increase of its advantage in the sector. In company "R", the indicator was above $20 \%$ from 2015 to 2017 and below 8\% from 2018; a similar situation is also seen in the company "N". However, the most stable NPR indicator is in company "N", which remained almost unchanged from 2017 to 2020; it is likely that COVID-19 did not significantly affect net profit. In companies " $\mathrm{J}$ " and "R", the indicator improved in 2020 compared to the previous years. Company " $\mathrm{J}$ " only operated profitably in 2018 and 2020. To determine whether COVID-19 had an impact on the growth of the profit of company "J" in 2020, additional studies are needed. In companies "B" and "K", the net profitability indicator decreased in 2020, which could have been caused by the quarantine in Lithuania.

ROA shows how much net profit is contained in one assets euro and what share of the assets is returned in the form of profit. When ROA is above $15 \%$, the situation is considered good, and when it is under $8 \%$, it is unsatisfactory; about $20 \%$ or more is considered very good (Tamulevičienè, 2016). From 2015 to 2020, ROA was the most stable in company "N": values comprised 16-35\% and there was no significant decrease in 2020. In the company "R", the indicator changed inconsistently from $0 \%$ to $30 \%$ over the same period, but in 2020 , it increased by $12 \%$ compared to 2019 (0\% in 2019), but this indicator does not show a good situation. In companies "J", "B" and "K", the indicator was extremely low and was below 6\% every year, while in 2020, compared to 2019, the indicator decreased in companies "B" and "K", and increased in company "J".

ROE shows the net profit per euro of equity capital. This indicator refers to the profitability of investments and a high value means high dividends. High value is considered from $20 \%$ and unsatisfactory value is less than $10 \%$ (Tamulevičienè, 2016). The trends of ROE change in selected companies from 2015 to 2020 are similar to trends of ROA change. In company " $\mathrm{N}$ ", the indicator was high and relatively constant over the period under consideration; the indicator in company "R" from 2015 to 2017 shows a good situation and an unsatisfactory one from 2018 to 2020. In contrast, in the remaining companies, this indicator was low throughout the period being analysed and increased in 2020 compared to 2019 in company "J" and decreased in companies "B" and "K". 


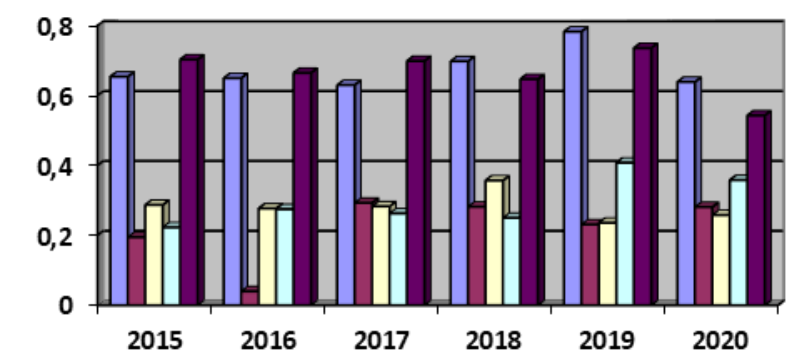

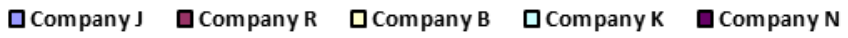

Figure 8. Total debt ratio (TDR) in Lithuanian road transport companies from 2015 to 2020

The TDR shows debts per assets euro (see Figure 8 for results). A high value of the indicator shows that most of the debts are not covered by assets, while a low value means the opposite. Companies whose indicator is low can receive loans easier. The indicator is considered to be good when it is under 0.5 (the best value is 0.2 (Steponavičiūte \& Kamarauskienè, 2016)), and unsatisfactory when it is above 0.7. The TDR of companies can be divided into two groups according to results: For companies " $\mathrm{J}$ " and "N", the TDR was high throughout the years analysed and it slightly decreased in 2020, while for companies " $R$ ", " $B$ " and " $K$ ", the indicator was rather stable and did not exceed 0.5 .

The CLR indicator, also known as the current liquidity ratio, shows the coverage of the current liabilities of the company with current assets, namely the amount of current assets per one euro of current liabilities. When the resulting value is less than 1 , it means that the company may not be able to cover current liabilities, a value between 1 and 2 is considered good, and when it exceeds 2, it means that the company uses the company's assets inefficiently (Kazakevičius \& Jakštas, 2018). The results are shown in Figure 9.

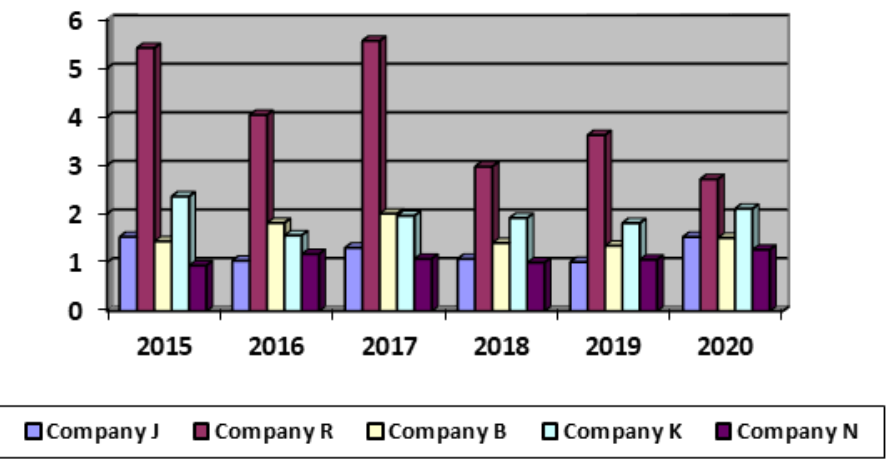

Figure 9. Current liquidity ratio (CLR) in Lithuanian road transport companies from 2015 to 2020

The obtained CLR results in Figure 9 highlight the following aspects: it is likely that company "R" used current assets inefficiently as CLR exceeded 2 from 2015 to 2020. CLR of company " $K$ " is close to 2, but throughout the years, with the exception of 2015 and 2020 close to the value of 2; it can be considered that the situation in the company is good. In companies " $\mathrm{J}$ ", "B" and " $\mathrm{N}$ ", the values of the indicator are within the recommended range, indicating that the companies effectively deal with current liabilities. 


\section{INSIGHTS INTO REGIONAL DEVELOPMENT}

ISSN 2669-0195 (online) http://jssidoi.org/jesi/

2021 Volume 3 Number 4 (December)

http://doi.org/10.9770/IRD.2021.3.4(3)

The calculated TSR is important for investors. It shows the ratio of equity capital per euro of debt. The indicator value of less than 0.5 is considered bad, about 1-2 is good, and a value above 2 means a very good situation; on the other hand, it may mean that the company has accumulated too many assets (Steponavičiūte \& Kamarauskiene, 2016). From 2015 to 2020, only the indicator of company "R" was above 2, meaning that own funds of the company exceeded borrowed funds. A similar situation is observed in company "K": from 2019 to 2020, the indicator was below 2, but within normal situation limits. Company "B" maintains a stable indicator throughout the period: from 1.15 to 1.63 , which shows a fairly good situation. The situation is the opposite in companies "J" and "N" since the TSR did not amount to 1 throughout the years and the majority of the companies' assets are borrowed. This gives investors a negative view of these companies.

The results of the calculations of financial relative indicators do not reflect the same change trends throughout the period and in 2020, as compared to the previous years. In several companies, the indicators improved, while in others, they deteriorated or remained relatively stable, so it is difficult to determine whether such changes were caused by the quarantine imposed in Lithuania because of the spread of COVID-19. The relative indicators method should be used with other methods to support or refute these conclusions.

\section{The impact of coronavirus-related quarantine on the financial results of Lithuanian road transport companies}

The calculations of the paired correlations coefficients and their weight highlighted a different connection between coronavirus and financial results in individual companies. The calculated paired correlation connections between the number of quarantine days $(Y)$ and each calculated relative indicator in the companies $(X)$ shows that the financial relative indicators of companies " $\mathrm{K}$ " and " $\mathrm{N}$ " are not dependent on the number of quarantine days in Lithuania. In other companies, at least one indicator was recorded that correlates with the number of quarantine days per quarters of 2020. For companies "J", "R" and "B", significant correlation coefficients and t values are given in Table 4.

Table 4. Correlation coefficients of relative financial indicators of the companies affected by the COVID-19 quarantine

\begin{tabular}{|c|c|c|c|c|c|c|c|c|}
\hline Company & Value & GPR & NPR & ROA & ROE & TDR & CLR & TSR \\
\hline \multirow{3}{*}{ Company J } & $r$ & -0.7766 & 0.3742 & 0.3829 & 0.3700 & -0.9858 & -0.2521 & 0.9801 \\
\cline { 2 - 9 } & $t^{\text {tab }}$ & 1.7431 & 0.5707 & 0.5862 & 0.5632 & 8.2969 & 0.3685 & 6.9758 \\
\cline { 2 - 9 } & $t^{\text {stat }}$ & 4.3027 & 4.3027 & 4.3027 & 4.3027 & 4.3027 & 4.3027 & 4.3027 \\
\hline \multirow{3}{*}{ Company R } & $r$ & -0.9908 & 0.3756 & 0.6029 & 0.5877 & 0.2337 & -0.4587 & -0.3824 \\
\cline { 2 - 9 } & $t^{\text {tab }}$ & 10.3612 & 0.5732 & 1.0687 & 1.0273 & 0.3400 & 0.7299 & 0.5853 \\
\cline { 2 - 9 } Company B & $t^{\text {stat }}$ & 4.3027 & 4.3027 & 4.3027 & 4.3027 & 4.3027 & 4.3027 & 4.3027 \\
\hline & $r$ & -0.4815 & -0.9955 & 0.9672 & 0.9855 & -0.3114 & 0.4580 & 0.3382 \\
\cline { 2 - 9 } & $t^{\text {tab }}$ & 0.7769 & 14.7819 & 5.3886 & 8.2032 & 0.4635 & 0.7287 & 0.5082 \\
\cline { 2 - 9 } & $t^{\text {stat }}$ & 4.3027 & 4.3027 & 4.3027 & 4.3027 & 4.3027 & 4.3027 & 4.3027 \\
\hline
\end{tabular}

Table 4 shows in italics the paired correlations coefficients that are significant. In company "J", there is a strong negative impact of the quarantine on the total debt ratio $(r=-0.9858)$ and a strong positive impact on the total solvency ratio $(r=0.9801)$. This means that the TDR indicator decreased with the increase in the number of quarantine days, which means that the debt of company " $\mathrm{J}$ " was better covered by assets and the value of the indicator improved. The TSR indicator increased with the increase in the number of quarantine days. This shows that the company's own funds exceed its debt and that the indicator is improving in 2020. The results of the correlation analysis show that the quarantine effect on company "J" is positive.

In company " $R$ ", the correlation coefficient is only significant in the case of overall profitability $(r=-0.9908)$ and there is a strong negative correlation. As the number of quarantine days in Lithuania increased, overall 


\section{INSIGHTS INTO REGIONAL DEVELOPMENT}

ISSN 2669-0195 (online) http://jssidoi.org/jesi/

2021 Volume 3 Number 4 (December)

http://doi.org/10.9770/IRD.2021.3.4(3)

profitability in company " $\mathrm{R}$ " decreased. This may mean that the benefits of the services sold by the company are decreasing, which may have been caused by quarantine restrictions, and that a restructuring of pricing is needed.

Three significant correlation coefficients were obtained in company "B": net profitability $(r=-0.9955)$, return on assets $(r=0.9672)$ and return on equity $(r=0.9855)$. The strongest impact of quarantine on the financial results of the company compared to other companies was observed in this case. As the number of quarantine days increased, the NPR decreased: there was a strong negative correlation between the two. That is, in 2020, the competitiveness of transport services in company "B" decreased. In contrast, ROA and ROE indicators were affected differently: they increased with the increase in the number of quarantine days. A strong positive correlation is observed. This means that the company was able to use its assets profitably, had sufficient reserves, and the return on the money invested by the owners increased as well. It is stated that the opposite effect on different profitability indicators is normal as this also depends on the assets available, equity, and other indicators as well as on decisions taken in the company (Savickas, 2019).

The correlation analysis shows that the crisis caused by COVID-19 and the quarantine imposed in Lithuania affect road transport companies operating in the transport sector differently. The financial relative indicators of two of the five companies in 2020 were not dependent on quarantine and it is likely that their activities were not restricted during quarantine. The results of other companies were affected differently: two companies experienced a partially positive effect, one of which was also affected negatively, and only one company experienced negative effects because of quarantine. However, the coefficients calculated are not the only way to identify the effects and it is likely that all companies being studied may have been affected by quarantine restrictions in one way or another. This requires more detailed research and performing the same calculations with the financial data of transport companies for 2021.

\section{Conclusions}

After the analysis of scientific literature and empirical research, it can be stated that coronavirus affects companies in the road transport sector in Lithuania differently. The scientific literature emphasises the strong negative impact on air transport activities, on all public transport, partially positive impact on rail freight transport, while road transport in the context of COVID-19, which is likely to have been affected by the pandemic the least, is analysed insufficiently. In general, the outbreak of coronavirus caused market imbalance in the transport sector due to announced quarantine restrictions, which affected companies' profitability indicators, changes in sales costs and income in one way or another.

The methodology consists of an expert survey, a calculation of relative indicators and a paired correlation analysis, thereby analysing the impact of COVID-19 on the financial results of transport companies in several stages and producing more accurate research results.

The empirical study confirmed the following hypothesis: the financial results of the investigated Lithuanian road transport companies are not affected in the same way by the crisis caused by COVID-19:

- The expert survey showed that the opinions of ten experts are not coordinated $(\mathrm{W}=0.2244)$ and this may mean that the consequences of COVID-19 were different in their companies ( $70 \%$ of the experts confirmed positive or negative effects of COVID-19 on the companies). Demand for transport services decreased for $30 \%$ of the companies, and increased for $40 \%$, while supply decreased for $20 \%$ and increased for $30 \%$, and remained unchanged in the rest of the companies. The calculated weight of the indicators shows that net profit, current liabilities, gross profit and sales revenue were affected the most. On the basis of the results obtained and literature analysis, appropriate relative indicators were selected. 


\section{INSIGHTS INTO REGIONAL DEVELOPMENT}

ISSN 2669-0195 (online) http://jssidoi.org/jesi/

2021 Volume 3 Number 4 (December)

http://doi.org/10.9770/IRD.2021.3.4(3)

- The calculations of relative indicators carried out from 2015 to 2020 showed that the changes in the GPR and ROE in 2020 are minimal in comparison with the previous years and COVID-19 impact is absent or minimal; ROA, TDR, CLR, TSR in individual companies changed inconsistently; therefore, it is likely that the indicators decreased or increased due to COVID-19 in some cases. More significant changes compared to other indicators are observed in the change of the NPR indicator: in 2020, it increased in some companies and decreased in others. After summarizing the analysis of the relative indicators from 2015 to 2020, it was found that the most efficient companies were "R" and "K", while the worst situation was in company "J". However, company "J" was the least affected by COVID-19 quarantine, while companies " $\mathrm{B}$ " and " $\mathrm{K}$ " were the most affected.

- The paired correlation analysis identified three out of five companies whose relative indicators were significantly affected in 2020 by the number of COVID-19 quarantine days. In company "J", quarantine had a strong positive effect on the TDR and TSR indicators, in company "R", GPR was very negatively affected, and in company " $\mathrm{B}$ " the following correlation coefficients were significant: NPR was very negatively affected and ROA and ROE were affected very positively, suggesting that the coronavirus crisis had a different effect on the financial results of road transport companies.

In order to identify the exact impact of coronavirus on the financial results of companies in the transport sector better, it is recommended that a more detailed study be carried out to include financial data of 2021 from more companies operating in different modes of transport, and that additional research methods be used.

\section{References}

Abate, M., Christidis, P., \& Purwanto, A. J. (2020). Government support to airlines in the aftermath of the COVID-19 pandemic. Journal of Air Transport Management, 101931. https://doi.org/10.1016/j.jairtraman.2020.101931

Ajam, T. (2020). The economic costs of the pandemic-and its response. South African Journal of Science, 116(7/8). https://doi.org/10.17159/sajs.2020/8490

Baak, M., Koopman, R., Snoek, H., \& Klous, S. (2020). A new correlation coefficient between categorical, ordinal and interval variables with Pearson characteristics. Computational Statistics and Data Analysis, 152, 107043. https://doi.org/10.1016/j.csda.2020.107043

Baležentis, A., \& Žalimaitė, M. (2011). Ekspertinių vertinimų taikymas inovacijų plètros veiksnių analizejje: Lietuvos inovatyvių įmonių vertinimas (Application of expert evaluations in the analysis of innovation development factors: Evaluation of Lithuanian innovative companies). Management Theory and Studies for Rural Business and Infrastructure Development, 3 (27). Research papers. http://mts.asu.lt/mtsrbid/article/viewFile/269/298

Barua, S. (2020). Understanding Coronanomics: The Economic Implications of the Coronavirus (COVID-19) Pandemic. SSRN Electronic Journal. https://doi.org/10.2139/ssrn.3566477

Bilevičienè, T., \& Jonušauskas, S. (2011). Statistiniu metodu taikymas rinkos tyrimuose (Application of statistical methods in market research). Vadovelis. Mykolo Romerio universtitetas. https://repository.mruni.eu/bitstream/handle/007/16758/9789955192770.pdf?sequence=1

Bliekienè, R., \& Stundžienè, A. (2012). Ekonomikos svyravimų įtaka įmonių veiklos rezultatams (Influence of economic fluctuations on the performance of companies). Verslas: Teorija Ir Praktika, 13(1), 5-17. https://www.ceeol.com/search/article-detail?id=23014

Delen, D., Kuzey, C., \& Uyar, A. (2013). Measuring firm performance using financial ratios: A decision tree approach. Expert Systems with Applications, 40(10), 3970-3983. https://doi.org/10.1016/j.eswa.2013.01.012

Fenyves, V., Zsido, K. E., Bircea, I., \& Tarnoczi, T. (2020). Financial performance of Hungarian and Romanian retail food small businesses. British Food Journal, 122(11), 3451-3471. https://doi.org/10.1108/BFJ-05-2019-0330

Hu, S., \& Zhang, Y. (2021). COVID-19 pandemic and firm performance: Cross-country evidence. International Review of Economics and 


\section{INSIGHTS INTO REGIONAL DEVELOPMENT}

ISSN 2669-0195 (online) http://jssidoi.org/jesi/

2021 Volume 3 Number 4 (December)

http://doi.org/10.9770/IRD.2021.3.4(3)

Finance, 74, 365-372. https://doi.org/10.1016/j.iref.2021.03.016

ICAO. (2020). Effects of Novel Coronavirus (COVID-19) on Civil Aviation: Economic Impact Analysis Air Transport Bureau Contents. https://www.icao.int/sustainability/Documents/COVID-19/ICAO_Coronavirus_Econ_Impact.pdf

Jenelius, E., \& Cebecauer, M. (2020). Impacts of COVID-19 on public transport ridership in Sweden: Analysis of ticket validations, sales and passenger counts. Transportation Research Interdisciplinary Perspectives, 8, 100242. https://doi.org/10.1016/j.trip.2020.100242

Kadim, A., Sunardi, N., \& Husain, T. (2020). The modeling firm's value based on financial ratios, intellectual capital and dividend policy. https://doi.org/10.5267/j.ac.2020.5.008

Kardelis, K. (2017). Moksliniu tyrimu metodologija ir metodai (Research methodology and methods). Vadovélis. Mokslo ir enciklopedijų leidybos centras.

Kazakevičius, A., \& Jakštas, E. (2018). Verslo ịmoniu finansiniu ataskaitu analize (Analysis of financial statements of business enterprises). Mokomoji knyga. Kauno kolegijos Reklamos ir medijų centras. http://dspace.kaunokolegija.lt//handle/123456789/149

Kendall, M. (1970). Rank correlation methods (4th ed.). Griffin.

Khatib, S., \& Nour, A.-N. I. (2021). The Impact of Corporate Governance on Firm Performance During The COVID-19 Pandemic: Evidence from Malaysia. Ournal of Asian Finance, Economics and Business, 8(2), 0943-0952. https://doi.org/10.1016/j.jairtraman.2020.101931

Lietuvos statistikos departamentas. (2021). Oficialiosios statistikos portalas (Official Statistics Portal). https://osp.stat.gov.lt/

Linares-Mustarós, S., Coenders, G., \& Vives-Mestres, M. (2018). Financial performance and distress profiles. From classification according to financial ratios to compositional classification. Advances in Accounting, 40, 1-10. https://doi.org/10.1016/j.adiac.2017.10.003

Liu, W., Liang, Y., Bao, X., Qin, J., \& Lim, M. K. (2020). China's logistics development trends in the post COVID-19 era. International Journal of Logistics Research and Applications, 1-12. https://doi.org/10.1080/13675567.2020.1837760

Loske, D. (2020). The impact of COVID-19 on transport volume and freight capacity dynamics: An empirical analysis in German food retail logistics. Transportation Research Interdisciplinary Perspectives, 6, 100165. https://doi.org/10.1016/j.trip.2020.100165

Mackevičius, J., \& Valkauskas, R. (2010). Integruota įmonès finansinès būklès ir veiklos rezultatu analizès metodika (Integrated methodology of the company's financial condition and performance analysis). Verslas: Teorija Ir Praktika, 3, $213-221$. https://epublications.vu.lt/object/elaba:4290300/

Maryla, M., Aaditya, M., \& van der Mensbrugghe, D. (2020). The Potential Impact of COVID-19 on GDP and Trade. SSRN Electronic Journal. https://doi.org/10.1596/1813-9450-9211

Nicola, M., Alsafi, Z., Sohrabi, C., Kerwan, A., Al-Jabir, A., Iosifidis, C., Agha, M., \& Agha, R. (2020). The socio-economic implications of the coronavirus pandemic (COVID-19): A review. In International Journal of Surgery (Vol. 78, pp. 185-193). Elsevier Ltd. https://doi.org/10.1016/j.ijsu.2020.04.018

Ozaydin, O., \& Ulengin, F. (2020). Impacts of COVID-19 on the Transport Sector and Measures as Well as Recommendations of Policies and Future Research: A Report on Turkey. SSRN Electronic Journal. https://doi.org/10.2139/ssrn.3686628

Pabedinskaitė, A., \& Činčikaitè, R. (2016). Kiekybiniai modeliavimo metodai. Vilnius Gediminas Technical University. https://doi.org/10.20334/1563-s

Petryk, V. L. (2020). An Analysis of the Global Civil Aviation Market and a Forecast of its Development in the Face of Unstable Demand for Air Transportation. Business Inform, 3(506), 112-119. https://doi.org/10.32983/2222-4459-2020-3-112-119

Podvezko, V. (2004). Agreement of expert estimates, Technological and Economic Development of Economy. 11(2), 101-107. https://doi.org/10.1080/13928619.2005.9637688

Poteliūnienė, N., Andruškevič, A., Leipus, A., Keršienė, D., Bagdžiūnienė, I., Stankevič, J., Klepikovaitė, K., Čepauskaitė, S., Guobienė, R., Pupeikytė-Usačiova, R., \& Obcarskienè, R. (2020). COVID-19 krizès ir ekstremaliosios situacijos valdymas (COVID-19 Crisis 


\section{INSIGHTS INTO REGIONAL DEVELOPMENT}

ISSN 2669-0195 (online) http://jssidoi.org/jesi/

2021 Volume 3 Number 4 (December)

http://doi.org/10.9770/IRD.2021.3.4(3)

and Emergency Management). Aukščiausioji Audito Institucija.

Rababah, A., Al-Haddad, L., Sial, M. S., Chunmei, Z., \& Cherian, J. (2020). Analyzing the effects of COVID-19 pandemic on the financial performance of Chinese listed companies. Journal of Public Affairs, 20(4), e2440. https://doi.org/10.1002/pa.2440

Sahoo, P., \& Ashwani. (2020). COVID-19 and Indian Economy: Impact on Growth, Manufacturing, Trade and MSME Sector. Global Business Review, 21(5), 1159-1183. https://doi.org/10.1177/0972150920945687

Savickas, V. (2019). Issues in selecting profitability indicators for the evaluation of corporate financial performance. Buhalterines Apskaitos Teorija Ir Praktika, 20, 6. https://doi.org/10.15388/batp.2019.14

Serrano, F., \& Kazda, A. (2020). The future of airport post COVID-19. Journal of Air Transport Management, 89, 101900. https://doi.org/10.1016/j.jairtraman.2020.101900

Shen, H., Fu, M., Pan, H., Yu, Z., \& Chen, Y. (2020). The Impact of the COVID-19 Pandemic on Firm Performance. Emerging Markets Finance and Trade, 56(10), 2213-2230. https://doi.org/10.1080/1540496X.2020.1785863

Steponavičiūtè, E., \& Kamarauskienè, I. (2016). Santykinių rodiklių taikymas viešojo sektoriaus subjektuose (bendrojo lavinimo įstaigų pavyzdžiu). Application of financial ratios in public sector entities (on the example of general education institutions) $V U E F$ Studenty Mokslinès Draugijos Konferencijos Straipsniu Rinkinys, 211-222.

Tamulevičienė, D. (2016). Methodology of complex analysis of companies' profitability. Enterpreneurship and Sustainability Issues, 4(1). https://doi.org/10.9770/jesi.2016.4.1(5)

Tardivo, A., Sánchez, C., Armando, M., Zanuy, C., Martín, C. S., Carrillo Zanuy, A., \& Zanuy, A. C. (2020). COVID-19 impact in transport, an essay from the railways' systems research perspective. https://www.worldometers.info/coronavirus/

Thacker, P. G., Witte, R. J., \& Menaker, R. (2020). Key financial indicators and ratios: How to use them for success in your practice. Clinical Imaging, 64, 80-84. Elsevier Inc. https://doi.org/10.1016/j.clinimag.2020.03.015

Paulina PERIOKAITÉ is a bachelor of economics. Her research interests are: transport sector, COVID-19, economic crisis. ORCID ID: orcid.org/0000-0002-1178-9620

Dr Nomeda DOBROVOLSKIENE is an Associate Professor of the Department of Financial Engineering, Faculty of Business Management at Vilnius Gediminas Technical University, Lithuania. Her research interests are: Projects, Project Management, Project Portfolio, Project Portfolio Management, Sustainability, Multi-Criteria Decision-Making, transport sector, economic crisis.

ORCID ID: orcid.org/0000-0002-1606-9980

Make your research more visible, join the Twitter account of INSIGHTS INTO REGIONAL DEVELOPMENT:

@ IntoInsights

Copyright (C) 2021 by author(s) and VsI Entrepreneurship and Sustainability Center

This work is licensed under the Creative Commons Attribution International License (CC BY).

http://creativecommons.org/licenses/by/4.0/

CC) (i) Open Access 